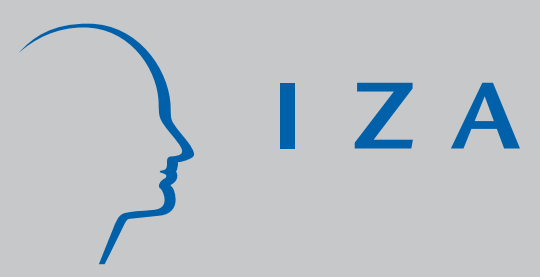

IZA DP No. 475

A Macroeconomic Experiment in Mass Immigration

Zvi Hercowitz

Eran Yashiv

April 2002 


\title{
A Macroeconomic Experiment in Mass Immigration
}

\author{
Zvi Hercowitz \\ Tel Aviv University \\ Eran Yashiv \\ Tel Aviv University, CEPR and IZA, Bonn
Discussion Paper No. 475
April 2002 \\ IZA \\ P.O. Box 7240 \\ D-53072 Bonn \\ Germany \\ Tel.: +49-228-3894-0 \\ Fax: +49-228-3894-210 \\ Email: iza@iza.org
}

This Discussion Paper is issued within the framework of IZA's research area Mobility and Flexibility of Labor. Any opinions expressed here are those of the author(s) and not those of the institute. Research disseminated by IZA may include views on policy, but the institute itself takes no institutional policy positions.

The Institute for the Study of Labor (IZA) in Bonn is a local and virtual international research center and a place of communication between science, politics and business. IZA is an independent, nonprofit limited liability company (Gesellschaft mit beschränkter Haftung) supported by the Deutsche Post AG. The center is associated with the University of Bonn and offers a stimulating research environment through its research networks, research support, and visitors and doctoral programs. IZA engages in (i) original and internationally competitive research in all fields of labor economics, (ii) development of policy concepts, and (iii) dissemination of research results and concepts to the interested public. The current research program deals with (1) mobility and flexibility of labor, (2) internationalization of labor markets, (3) welfare state and labor markets, (4) labor markets in transition countries, (5) the future of labor, (6) evaluation of labor market policies and projects and (7) general labor economics.

IZA Discussion Papers often represent preliminary work and are circulated to encourage discussion. Citation of such a paper should account for its provisional character. A revised version may be available on the IZA website (www.iza.org) or directly from the author. 
IZA Discussion Paper No. 475

April 2002

\section{ABSTRACT}

\section{A Macroeconomic Experiment in Mass Immigration*}

This paper studies the effects of mass immigration from the former USSR to Israel in the 1990s on the employment of the native-born. The exogeneity and the size of this inflow make it a "natural experiment" of macroeconomic proportions. An open-economy macroeconomic model is used to analyze this experience, focusing on the differential entry of immigrants into the labor and goods markets and the ensuing dynamic implications for labor demand. The reduced form of the model - consisting of two equations for native employment and the relative price of domestic goods - is estimated, finding negative effects of immigration on native employment a year after arrival. The delay in the effect is attributed to a positive impact of immigration on the excess demand for goods and, thus, on the demand for labor earlier on.

JEL Classification: E24, F16, J61

Keywords: immigration, open economy, natives employment

Eran Yashiv

Berglas School

Tel Aviv University

Tel Aviv 69978

Israel

Tel.: +972-3-640 9233

Fax: +972-3-640 9908

Email: yashiv@post.tau.ac.il

\footnotetext{
${ }^{*}$ We thank Nathan Sosner and Guy Navon for able research assistance and the Sapir Center at Tel Aviv University for financial support. Any errors are our own.
} 


\section{Introduction}

During the 1990s, a wave of mass immigration arrived in Israel from the former USSR: more than 800,000 immigrants entered the country within 10 years (1990-1999), representing an $18 \%$ increase in the population. An important aspect of this immigration experience is that it may be considered exogenous. It was generated by the opening of the emigration gates, as well as by the worsening political and economic conditions in the former USSR. Furthermore, due to changes in US immigration laws and the existence of tough European laws, Israel seemed to be the main option for Jewish emigrants. With its large variation during the decade, this wave of immigration offers a unique opportunity - a "natural experiment" - to examine the dynamic effects of immigration on the employment of the native-born. This paper studies these effects in a macroeconomic setup, which incorporates indirect effects via the goods market. The reduced form of the model is estimated.

While negative effects of immigration on the employment of the native-born may be expected, the evidence in the literature indicates surprisingly small effects. Borjas (1994, see in particular pp. 1695-1700 $)^{1}$, who reviewed and discussed this literature, points to two major conclusions: (i) immigration has a weak effect on the employment of the native-born even when the immigrant flows are large; (ii) this finding may be explained by outflows of native-born workers from localities or industries affected by immigration to other areas of the economy. One example is Card's (1990) study of the Cuban Mariel boatlift to Miami in 1980. Though Miami's labor force had grown by $7 \%$ almost overnight, the effects on the wages and employment of locals were very small. Zimmermann (1995, in particular pp. 53-54) points to similar conclusions for Europe.

This issue is re-examined here in a macroeconomic setup, focusing on the dynamic effects. The analysis is based on an open-economy framework of the type developed by Bruno and Sachs (1985) and Altonji and Card (1991). It allows for immigration effects on

\footnotetext{
${ }^{1}$ For related discussions, see Borjas, Freeman and Katz (1997), Friedberg and Hunt (1995) and Zimmermann (1995).
} 
both labor supply and labor demand - the latter working through the goods market.

A key feature of the model is the differential entry of immigrants into the labor and goods markets. Immigrants' participation in the labor market is related to the supply of domestic goods, while their participation in the goods market is related to the demand for these goods. Hence, differential entry generates changes in the relative price of domestic goods, which, in turn, affects labor demand and the employment of the native-born. In particular, the presumption here is that during the early stages after immigration, participation in the goods market is likely to be relatively stronger. This increases the relative price of domestic goods, having a positive effect on labor demand and native-born employment. Later on, relative participation in the labor market (or, indirectly, in the supply of goods) is likely to dominate, causing an opposite effect: a decline in the relative price of goods, lower labor demand and lower native-born employment. If differential participation is important only during a transition, the mechanism described above should be temporary.

Beyond the mechanism of differential participation and relative price adjustment, the conventional mechanism of direct labor substitution of immigrants for native-born workers is also considered. These two effects are characterized in the model by looking at two cases. One is imperfect mobility of capital and other imported inputs, where the labor substitution mechanism operates alongside the differential participation effect. The other is perfect mobility of capital and imported inputs, where labor demand adjusts immediately as immigrants enter the labor market, and hence the substitution effect is neutralized. In this case, without differential participation in the labor and goods markets, the real wage and employment of native-born remain unchanged. Both cases are nested in a single setup, depending on the value of a key parameter.

The paper proceeds as follows: Section 2 discusses the Israeli immigration experience and reports relevant findings from previous studies. Section 3 presents the model. The data and the econometric approach are discussed in Section 4. Section 5 presents the results and Section 6 concludes. 


\section{The Israeli Immigration Experience in the 1990s}

The immigration influx from the former USSR started at the end of $1989 .{ }^{2}$ Figure 1 shows the quarterly flows of working-age immigrants as percentages of the corresponding native-born population during the 1990s. The immigration flows were particularly high in 1990-1991, with a brief decline in early 1991 due to the Gulf War. At the peak, 50,000 working-age immigrants arrived in one quarter - about $1.8 \%$ of the native working-age population. In the second part of 1991, the flow began to decline dramatically to around 10,000 per quarter, or $0.3 \%$ of the working-age population. Given this variation, the 1990s can be considered a "natural experiment" in immigration of macroeconomic proportions.

\section{Figure 1}

A central issue in the present analysis is the effects of immigration on the goods market and on the relative price of imported goods (the "real exchange rate"), or the inverse of the relative price of domestic goods. Figure 2 plots the relative price of imports - the index of import prices divided by the deflator of business sector GDP. The relative price has a declining trend, which seems to reflect the Balassa-Samuelson effect. It can be observed that the large immigration flows are followed by a fast drop and then by a much more moderate decline.

\section{Figure 2}

Three recent studies addressing this immigration episode present microeconomic evidence that is important for the present macroeconomic analysis. Friedberg (1997) studied the migrants' effects cross-sectionally. Using microdata from the Income Survey and the Labor Force Survey of the Israeli Central Bureau of Statistics, she finds - consistent with

\footnotetext{
${ }^{2}$ The macroeconomic developments during the 1980s were dominated by hyperinflation and stabilization. The historical perspective on the main variables is discussed in an appendix available from the authors.
} 
the cited literature - no significant effects on wages or employment of the native-born across occupations. ${ }^{3}$ Note that these findings refer to the stock of immigrants. Eckstein and Shachar (1996) estimated the mean duration between arrival and the first full-time job, finding a range between 12 and 25 months. This implies gradual entry of immigrants into the labor market. It should be noted that each immigrant was entitled to a governmentprovided "absorption basket" that included monthly cash transfers and a rent allowance. Hence, even credit-constrained immigrants may have delayed entry into the labor market, if they so desired, in order to learn the language, become acquainted with labor market procedures, etcetera. Eckstein and Weiss (1998) found that, upon arrival, immigrants got no return for their imported skills, but that the prices of these skills rose gradually with the length of stay.

Summarizing, the "absorption basket," immediate housing and consumption needs, and the evidence on gradual entry into the labor market stress the importance of differential entry into the goods and labor markets, and, in particular, stronger participation in the goods market at the earlier stages following immigration.

\section{The M odel}

The following model is a version of the open-economy framework used by Bruno and Sachs (1985, Chapter 5) and, in an urban immigration context, by Altonji and Card (1991). Assuming openness of the economy to trade seems natural for an economy which is open to immigration. A key variable in this context is the relative price of the domestic good in terms of the imported good. ${ }^{4}$ The model has the following key features:

(i) It incorporates differential entry of immigrants into the labor and goods markets.

\footnotetext{
${ }^{3}$ With OLS estimation, significant effects are found. However, when the pre-immigration occupational distribution is used to instrument the post-immigration distribution, the coefficients turn insignificant. Friedberg explains the OLS results by a bias induced by immigrants entering low wage-growth occupations.

${ }^{4}$ In an economy that is closed to trade, immigration would trigger changes in the intertemporal relative price of goods, or the real interest rate, which shift the supply of native-born labor. In the current setup, it
} 
(ii) It focuses on the short-run dynamic effects of immigration flows, allowing for the possibility that the stock of immigrants does not affect native employment, as found in the literature.

Consider an open economy that specializes in the production of good $Y$, facing a downward sloping demand function. Production requires the inputs of labor, $L$, and imported good $M$-including capital services and intermediate inputs. The economy faces a perfectly elastic supply of $M$ at the price $P_{m}^{*}$, and costless adjustment of $M$. For simplicity, we abstract from technological progress. The aggregate production function is:

$$
Y=L^{\alpha} M^{\beta} M_{0}^{1-\alpha-\beta}, \quad 0<\alpha<1, \quad 0<\beta<1, \quad \alpha+\beta \leq 1
$$

Two cases are considered: (i) constant returns on $L$ and $M$, and (ii) diminishing returns, given an unadjustable additional input $M_{0}$. The first represents perfect capital mobility, and the second captures, in a simple way, imperfect capital mobility. ${ }^{5}$

Labor is supplied by two types of workers: native-born $(N)$ and immigrants $(I)$. The (working-age) population of each type is exogenous and is denoted by $P_{N}$ and $P_{I}$ respectively. The native-born population grows at a constant rate, while the immigrant population is

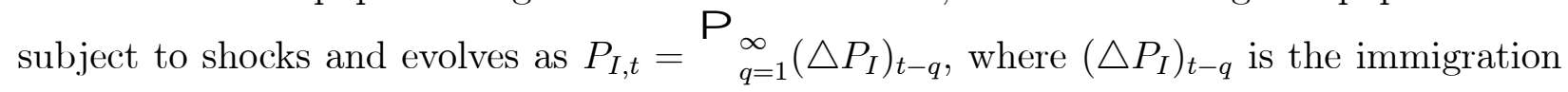
flow with a lag of $q$ periods. It is assumed that $M_{0} / P_{N}$ is constant-i.e., $M_{0}$ grows at the same rate as that of the native-born population. What is important in the present context is that $M_{0}$ does not react to the immigration flows.

The demands for labor and for imported inputs are implied by the conditions:

$$
\begin{gathered}
\alpha L^{\alpha-1} M^{\beta} M_{0}^{1-\alpha-\beta}=w, \\
\beta L^{\alpha} M^{\beta-1} M_{0}^{1-\alpha-\beta}=p_{m},
\end{gathered}
$$

is the demand for labor that is affected by the excess demand for goods.

${ }^{5}$ These two cases allow for closed-form solutions of the model, which can be estimated. 
where $w$ is the wage in terms of the domestic good and $p_{m}$ is the price of imported inputs in terms of the domestic good, or the "real exchange rate." The macroeconomic mechanism, to be described below, works via $p_{m}$.

The labor supply functions of the native-born and of immigrants are specified as:

$$
\begin{gathered}
L_{N}=w^{\lambda} P_{N}, \quad \lambda>0, \\
L_{I}=w^{\lambda} \overline{\Delta P_{I}} \bar{\theta}_{l}
\end{gathered}
$$

where $\overline{\Delta P_{I}} \equiv\left\{\left(\Delta P_{I}\right)_{-1},\left(\Delta P_{I}\right)_{-2}, ..\right\}$ is the vector of immigration flows-which are not lumped into stocks in order to focus on gradual and differential entry into the labor and goods markets - and $\overline{\theta_{l}} \equiv\left\{\left(\theta_{l}\right)_{-1},\left(\theta_{l}\right)_{-2}, \ldots\right\}$ is a transposed exogenous vector of equal length, defined as immigrant "labor-participation factors." The corresponding factor for native-born is 1 . Given the process of learning the domestic language, labor market procedures and so forth, $\left(\theta_{l}\right)_{-q}$ is expected to increase with $q$, and to approach 1 from below. ${ }^{6}$

From (2), (4) and (5), labor market equilibrium requires:

$$
\alpha L^{\alpha-1} M^{\beta} M_{0}^{1-\alpha-\beta}={\frac{L}{P_{N}+\overline{\Delta P}_{I} \bar{\theta}_{l}}}^{\text {ी }_{\frac{1}{\lambda}}} .
$$

From (3) and (6), the solution for $L$ and $M$ in terms of $p_{m}$ and $P_{N}+\overline{\Delta P}_{I} \overline{\theta_{l}}$ is:

$$
\begin{gathered}
L=Z_{1} M_{0}^{\frac{\lambda(1-\alpha-\beta)}{\lambda(1-\alpha-\beta)+1-\beta}}\left(P_{N}+\overline{\Delta P_{I}} \overline{\theta_{l}}\right)^{\frac{1-\beta}{\lambda(1-\alpha-\beta)+1-\beta}} p_{m}^{\frac{-\lambda \beta}{\lambda(1-\alpha-\beta)+1-\beta}}, \\
M=Z_{2} M_{0}^{\frac{(1-\alpha-\beta)(1+\lambda)}{\lambda(1-\alpha-\beta)+1-\beta}}\left(P_{N}+\overline{\Delta P_{I}} \overline{\theta_{l}}\right)^{\frac{\alpha}{\lambda(1-\alpha-\beta)+1-\beta}} p_{m}^{-\frac{\lambda(1-\alpha-\beta)+1-\beta+\lambda \alpha \beta}{(1-\beta)(\lambda(1-\alpha-\beta)+1-\beta]}},
\end{gathered}
$$

\footnotetext{
${ }^{6}$ This seems consistent with the finding in Eckstein and Weiss (1998) of a rise in the prices of imported skills with the length of stay. Note that $w^{\lambda}$ represents the participation rate for native-born (we abstract from factors other than the wage) and $w^{\lambda}\left(\theta_{l}\right)_{-q}$ is the participation rate for immigrants with a length-of-stay of $q$ periods.
} 
where $Z_{1}, Z_{2}$-and the terms $Z_{3}, Z_{4}, \ldots$, below - are constants. Because of complementarity in production, the immigration flows affects positively, and the relative price of imports affects negatively, both total employment and intermediate goods imports.

Substituting (7), (8) into (2), and the resulting expression for $w$ into (4), yields:

$$
\frac{L_{N}}{P_{N}}=Z_{1} M_{0}^{\frac{\lambda(1-\alpha-\beta)}{\lambda(1-\alpha-\beta)+1-\beta}}\left(P_{N}+\overline{\Delta P_{I}} \bar{\theta}_{l}\right)^{\frac{-\lambda(1-\alpha-\beta)}{\lambda(1-\alpha-\beta)+1-\beta}} p_{m}^{\frac{-\lambda \beta}{\lambda(1-\alpha-\beta)+1-\beta}}
$$

Immigration has the standard negative effect on the employment rate of the native-born only if capital mobility is imperfect; otherwise, the exponent of $P_{N}+\overline{\Delta P}_{I} \bar{\theta}_{l}$ is zero. A decline in $p_{m}$ increases labor demand and, thus, the employment rate.

To close the system, it is necessary to spell out the equilibrium condition in the domestic good market and to solve for $p_{m}$. The supply function is derived by substituting the expressions for $L$ from (7) and for $M$ in (8) into the production function (1):

$$
Y^{s}=Z_{3} M_{0}^{\frac{(1-\alpha-\beta)(1+\lambda)}{\lambda(1-\alpha-\beta)+1-\beta}}\left(P_{N}+\overline{\Delta P_{I}} \bar{\theta}_{l}\right)^{\frac{\alpha}{\lambda(1-\alpha-\beta)+1-\beta}} p_{m}^{\frac{-\beta(1+\lambda)}{\lambda(1-\alpha-\beta)+1-\beta}}
$$

Supply increases in native population and in immigration - depending on its labor market participation - and decreases in the relative price of imports. Demand is specified as:

$$
Y^{d}=p_{m}^{\varepsilon}\left(P_{N}+\overline{\Delta P}_{I} \overline{\theta_{y}}\right), \quad \varepsilon>0
$$

where $\varepsilon$ is the relative price elasticity of demand and $\overline{\theta_{y}} \equiv\left\{\left(\theta_{y}\right)_{-1},\left(\theta_{y}\right)_{-2}, \ldots\right\}$ are the exogenous immigrant "participation factors" in the goods market, which are parallel to the $\overline{\theta_{l}}$ participation factors in the labor market. The magnitude of $\left(\theta_{y}\right)_{-q}$ is likely to be lower than 1 for low values of $q$, larger than 1 for higher $q$ 's, when immigrants invest in housing, for example, and it is expected to converge to 1 for sufficiently large $q$ 's.

The equilibrium condition $Y^{s}=Y^{d}$ implies that:

$$
p_{m}=Z_{4} M_{0}^{(1-\alpha-\beta)(1+\lambda) / \mu}\left(P_{N}+\overline{\Delta P}_{I} \overline{\theta_{y}}\right)^{-[\lambda(1-\alpha-\beta)+(1-\beta)] / \mu}\left(P_{N}+\overline{\Delta P}_{I} \bar{\theta}_{l}\right)^{\alpha / \mu}
$$


where $\mu \equiv \beta(1+\lambda)+\varepsilon \lambda(1-\alpha-\beta)+\varepsilon(1-\beta)>0$. Immigration has contradictory effects on the relative price. On the one hand, it raises the demand for goods and, thus, tends to lower $p_{m}$ (increase the relative price of $Y$ ), as indicated by the negative coefficient on the term containing $\overline{\theta_{y}}$. On the other hand, immigration increases labor supply and, thus, the supply of goods. Through this channel, immigration tends to increase $p_{m}$ - via the positive coefficient on the term containing $\overline{\theta_{l}} \cdot{ }^{7}$

The solution for native-born employment follows from (9) and (12):

$$
\frac{L_{N}}{P_{N}}=Z_{5} M_{0}^{\lambda \epsilon(1-\alpha-\beta) / \mu} P_{N}\left(1+\frac{\overline{\Delta P_{I}}}{P_{N}} \overline{\theta_{y}}\right)^{, \lambda \beta / \mu} P_{N}\left(1+\frac{\overline{\Delta P_{I}}}{P_{N}} \bar{\theta}_{l}\right)^{-\lambda[\beta+\epsilon(1-\alpha-\beta)] / \mu} .
$$

The effect of immigrants' participation in the goods market is expressed by the positive coefficient on the term with $\overline{\theta_{y}}$, while the effect of immigrants' participation in the labor market is expressed by the negative coefficient on the term with $\overline{\theta_{l}}$.

An empirically convenient formulation can be obtained by taking logs of (12) and (13). Using the approximation $\ln \left(1+\frac{\overline{\Delta P_{I}}}{P_{N}} \overline{\theta_{i}}\right) \simeq \frac{\overline{\Delta P_{I}}}{P_{N}}$ for $i=l, y$ yields: ${ }^{8}$

$$
\begin{aligned}
& \qquad \ln \frac{L_{N}}{P_{N}} \simeq \ln Z_{6}+{ }_{q=1}^{\chi_{\infty}}\left[\rho_{1}\left(\theta_{y}\right)_{-q}-\rho_{2}\left(\theta_{l}\right)_{-q}\right] \frac{\left(\Delta P_{I}\right)_{-q}}{P_{N}}, \\
& \rho_{1}=\lambda \beta / \mu>0, \\
& \rho_{2}=\{\lambda[\beta+\epsilon(1-\alpha-\beta)] / \mu\}>0, \\
& Z_{6}=Z_{5}{\frac{M_{0}}{P_{N}}}^{\rho_{2}-\rho_{1}},
\end{aligned}
$$

\footnotetext{
${ }^{7}$ If the model included a domestic component of $M$, immigration would affect the goods market and hence $p_{m}$, also via the investment demand for domestic goods. The implications for $p_{m}$, and for native employment, would be similar as those captured by the terms with $\overline{\theta_{y}}$, especially if investment of domestic goods is spread over time.

${ }^{8}$ This is a good approximation when $\frac{\overline{\Delta P_{1}}}{P_{\mathrm{N}}} \overline{\theta_{i}}, i=l, y$, is small enough relative to one. In the case under study, the accumulated immigration flows over the entire sample studied here reach less than $20 \%$ of the domestic population - and the $\theta$ factors should be, on average, less than one. Therefore, the approximation seems reasonable.
} 


$$
\begin{aligned}
& \ln p_{m} \simeq \ln Z_{7}{ }_{q=1}^{\chi_{\infty}}\left[\omega_{1}\left(\theta_{y}\right)_{-q}-\omega_{2}\left(\theta_{l}\right)_{-q}\right] \frac{\left(\Delta P_{I}\right)_{-q}}{P_{N}}, \\
& \omega_{1}=\{[\lambda(1-\alpha-\beta)+(1-\beta)] / \mu\}>0, \\
& \omega_{2}=\alpha / \mu_{3}>0, \\
& Z_{7}=Z_{4}{\frac{M_{0}}{P_{N}}}^{\omega_{2}-\omega_{1}} .
\end{aligned}
$$

Consider first the case of perfect capital mobility, or $1-\alpha-\beta=0$. This implies that $\rho_{1}=\rho_{2}$ and $\omega_{1}=\omega_{2}$ and, thus, the effects of immigration depend only on the difference $\left(\theta_{y}\right)_{-q}-\left(\theta_{l}\right)_{-q}$. If $\left(\theta_{y}\right)_{-q}-\left(\theta_{l}\right)_{-q}>0$-i.e., the impact on goods demand dominates-the $q$-lag immigration flow is associated with a lower $p_{m}$ (a higher relative price of $Y$ ) and higher $L_{N} / P_{N}$. If $\left(\theta_{y}\right)_{-q}-\left(\theta_{l}\right)_{-q}<0$, the impact on labor supply (and, thus, on goods supply) dominates, and then $\left(\Delta P_{I}\right)_{-q}$ brings about a higher $p_{m}$ and lower $L_{N} / P_{N}$. Hence, under perfect capital mobility, the effects depend only on the participation factors. This has two implications: First, if $\left(\theta_{y}\right)_{-q}=\left(\theta_{l}\right)_{-q}$ for all $q$, native employment and the relative price are not altered by immigration because perfect capital mobility eliminates the labor substitution mechanism. Second, for each $q$, the effects of immigration on native employment and the relative price should have opposite signs.

When capital mobility is imperfect, direct labor substitution does take place. Here, $1-\alpha-\beta>0$, and thus $\rho_{1}<\rho_{2}$ and $\omega_{1}>\omega_{2}$. To stress the direct labor substitution mechanism in (14), assume for a moment that $\left(\theta_{y}\right)_{-q}=\left(\theta_{l}\right)_{-q}$ for all $q$. Given that $\rho_{1}<\rho_{2}$, immigration now has the standard negative impact on $L_{N} / P_{N}$. Regarding the relative price in (15), from $\omega_{1}>\omega_{2}$ it follows that immigration has negative effects on $p_{m} \cdot{ }^{9}$ When $\left(\theta_{y}\right)_{-q} \neq\left(\theta_{l}\right)_{-q}$, both labor substitution and differential participation operate, and the net effect depends on the relative strengths of the two mechanisms at each lag. The sign of the immigration effect on native employment at lag $q$ depends on $\frac{\left(\theta_{y}\right)_{-q}}{\left(\theta_{l}\right)_{-q}} \mathrm{Q} \frac{\rho_{2}}{\rho_{1}}$. If goods market participation is high enough, relative to labor market participation at the same lag, it can offset the labor supply

\footnotetext{
${ }^{9}$ Compared with the case of perfect capital mobility, the decline in $p_{m}$ follows from the partial adjustment of capital and other inputs, which restricts the supply of domestic goods.
} 
substitution mechanism, represented by $\rho_{2} / \rho_{1}>1$. Higher $\left(\theta_{y}\right)_{-q}$ relative to $\left(\theta_{l}\right)_{-q}$ is also likely to cause an "appreciation," or decline in $p_{m}$, which requires that $\frac{\left(\theta_{y}\right)-q}{\left(\theta_{l}\right)-q}>\frac{\omega_{2}}{\omega_{1}}$.

Values of $\left(\theta_{y}\right)_{-q} /\left(\theta_{l}\right)_{-q}$ can be divided into five intervals, with a different combination of effects on $L_{N} / P_{N}$ and $p_{m}$. Table 1 shows these intervals, from high to low relative participation in the goods market, and the corresponding signs of the effects.

\section{Table 1}

\begin{tabular}{|c|c|c|c|}
\hline & \multicolumn{1}{|c|}{$\frac{\left(\theta_{y}\right)_{-q}}{\left(\theta_{l}\right)_{-q}}}$, & $\frac{L_{N}}{P_{N}}$ & $p_{m}$ \\
\hline \hline I & $1+\frac{\epsilon}{\beta}(1-\alpha-\beta), \infty$ & + & - \\
\hline II & $\frac{1}{3}+\frac{\epsilon}{\beta}(1-\alpha-\beta)$ & $=$ & - \\
\hline III & $1-\frac{(1+\lambda)(1-\alpha-\beta)}{\lambda(1-\alpha-\beta)+(1-\beta)}, 1+\frac{\epsilon}{\beta}(1-\alpha-\beta)$ & - & - \\
\hline IV & $\frac{1}{3}-\frac{(1+\lambda)(1-\alpha-\beta)}{\lambda(1-\alpha-\beta)+(1-\beta)}$, & - & $=$ \\
\hline V & $0,1-\frac{(1+\lambda)(1-\alpha-\beta)}{\lambda(1-\alpha-\beta)+(1-\beta)}$ & - & + \\
\hline
\end{tabular}

For example, interval I corresponds to a relative participation in the goods market that is high enough to generate a positive employment effect. In contrast, in interval $\mathrm{V}$, the labor substitution mechanism is reinforced by a depreciation, leading together to a negative employment effect. Unlike with perfect capital mobility, in general there should not be a negative relationship between the effects on the two variables: In regions I and V the effects have opposite signs, but in region III both effects are negative.

This model is consistent with no effect of the immigrant stock on native employment, as found in the literature. The stock includes flows with positive and negative values for $\rho_{1}\left(\theta_{y}\right)_{-q}-\rho_{2}\left(\theta_{l}\right)_{-q}$. Hence, lumping together all lags may average out these effects.

Finally, equation (5) implies that the real wage satisfies $w={\frac{L_{N}}{P_{N}}}^{1 / \lambda}$, i.e., the real wage should move together with the employment rate of the native-born.

\section{M ethodology and Data}

The equations for estimation are based on equations (14) and (15): 


$$
\begin{aligned}
& \ln \frac{L_{N, t}}{P_{N, t}}=a+b X_{t}+{ }_{q=1}^{X^{Q}} c_{q} \frac{\Delta P_{I, t-q}}{P_{N, t}}+\varepsilon_{t}, \\
& \ln p_{m, t}=a^{\prime}+b^{\prime} X_{t}+{ }_{q=1}^{X^{Q}} c_{q}^{\prime} \frac{\Delta P_{I, t-q}}{P_{N, t}}+\varepsilon_{t}^{\prime},
\end{aligned}
$$

where $X$ is a vector of controls (see below) and $\varepsilon_{t}, \varepsilon_{t}^{\prime}$ are error terms. The length of a period is taken as one quarter, and $Q$ is the empirically relevant number of lags. The equations are jointly estimated using a SUR procedure to allow for correlation of the error terms.

The purpose of the estimation is to organize the data in the form of "impulse responses" (expressed by $c_{q}, c_{q^{\prime}}, q=1,2, \ldots$ ) of the two endogenous variables to the immigration flows. According to the model, the coefficients have the form:

$$
\begin{aligned}
c_{q} & =\rho_{1}\left(\theta_{y}\right)_{-q}-\rho_{2}\left(\theta_{l}\right)_{-q}, \\
c_{q}^{\prime} & =-\omega_{1}\left(\theta_{y}\right)_{-q}+\omega_{2}\left(\theta_{l}\right)_{-q},
\end{aligned}
$$

$$
\begin{aligned}
& \rho_{1}=\lambda \beta / \mu>0, \\
& \rho_{2}=\{\lambda[\beta+\epsilon(1-\alpha-\beta)] / \mu\}>0, \\
& \omega_{1}=\{[\lambda(1-\alpha-\beta)+(1-\beta)] / \mu\}>0, \\
& \omega_{2}=\alpha / \mu>0 .
\end{aligned}
$$

The structural parameters are not identified. However, given that $\rho_{1}, \rho_{2}, \omega_{1}$ and $\omega_{2}$ enter in the same way in $c_{q}$ and $c_{q^{\prime}}$ for all $q$, the combinations of signs of these coefficients can trace, using Table 1, the relative strength of differential participation with the passage of time since migration.

A number of control variables are included to capture important macroeconomic developments not considered in the present model. First, a linear-quadratic time trend is included in both equations. In the relative price equation, the time trend is intended to capture the "Balassa-Samuelson" long-term decline in the relative price of imports, explained by technological change being biased towards tradeable goods. In the employment rate equation, the time trend is added to capture a longer term increase in the participation rate 
and the fact that the immigration influx started during a deep recession-hence, regardless of immigration, one may expect an increasing employment with the ensuing upturn.

The security and political situation is an exogenous factor that may be important to control for, as it could affect both macroeconomic activity and immigration. The sample period includes the Gulf War and waves of severe terrorist attacks in 1994 and particularly in 1996, as well as the Oslo Accord with the Palestinians in 1993 and the peace treaty with Jordan in 1994. The proxies chosen are: (i) inflows of tourists (tourists), and (ii) a political dummy variable $\left(d \_p o l\right)$ for the political party of the Prime Minister in office. ${ }^{10}$

The choice of the number of tourists as a proxy reflects the assumption that personal security has a much stronger effect on the desire to visit a country than do real exchange rate changes of the observed magnitude. The political dummy is intended to capture the feature that Labor-led governments tended to proceed faster than Likud-led governments with the peace process. An alternative interpretation of the political dummy is that the party in power reflects the security or political situation-i.e., when security deteriorates, the more militant party is elected. ${ }^{11}$

The chosen number of lags, $Q$, is 9 quarters, which seems a reasonably long period in the present context. Immigration flows prior to 1990, which were very small, are included so as not to shorten the sample with the number of lags. The coefficients on immigration lags are restricted to lie on a polynomial distributed lag (PDL), which imposes a parsimonious form on the impulse responses to immigration. The unrestricted form is also estimated.

The sample covers the period 1990-1999, at quarterly frequency. The immigration flows $\left(\Delta P_{I}\right)$ are taken from arrival records of working-age (15-64) immigrants from the former USSR. The labor force variables for the native-born - employment $\left(L_{N}\right)$ and working-age

\footnotetext{
${ }^{10}$ This variable takes the value of 1 when the prime minister is from the Labor Party (Rabin, Peres, and Barak) and 0 when the prime minister is from the Likud Party (Shamir and Netanyahu).

${ }^{11}$ The direction of the security situation effects on $L_{N} / P_{N}$ and $p_{m}$ depends on whether it influences more the demand side or the supply side of goods. If, for example, the main effect were on the production side, a better security situation should have positive effects on both variables.
} 
population $\left(P_{N}\right)$-are taken from the Labor Force Survey (also referring to the age group 15-64). The latter samples 11,400 households comprising 22,500 individuals $(0.6 \%$ of the relevant population). The relative price of imports $\left(p_{m}\right)$ is the index of import prices in domestic currency divided by the deflator of business sector GDP.

\section{Results}

Regression analysis of the main relations is reported in Section 5.1. Section 5.2 addresses additional relevant evidence.

\subsection{Regression A nalysis}

Table 2 presents the results of estimating equations (16) and (17). In the $p_{m}$ equation, the world price of oil in dollars was added to capture the drastic price hike induced by the Gulf crisis, given that the resulting jump in the relative price of imports coincided with large immigration flows.

\section{Table 2}

Specification 1 is as discussed above, while in Specification 2 the insignificant control variables were deleted. In Specification 3, the PDL restriction on the immigration coefficients was not imposed. The coefficients on immigration in Specification 2 are plotted, along with the $95 \%$ confidence band, in Figure 3.

\section{Figure 3}

The figure shows that the impulse response of employment is slightly positive (but not significant) at the first two lags, about zero at lag 3 , and then turns negative from lag 4 onwards. The impulse response of the real exchange rate is positive at the first lag and 
then turns negative from lag 2 onwards (though it is significant only at lags 4 and 5 ). In terms of Table 1, these responses can be seen as follows: At the first lag both responses are positive, inconsistent with the regions in Table 1, but highly insignificant. Lag 2 is in region I (positive effect for $L_{N} / P_{N}$ and negative for $p_{m}$ ), lag 3 is in region II (zero for $L_{N} / P_{N}$ and negative for $p_{m}$ ), and lag 4 and onwards are in region III (negative for both $L_{N} / P_{N}$ and $p_{m}$ ).

The main point is that the impulse responses can be interpreted as a downward movement along the regions of Table 1 -i.e., a decline in the relative participation in the goods market with the length of stay. The process can be described as follows: For two or three quarters after arrival, immigrants' relative participation in the goods market is the highest, and the ensuing increase in labor demand - due to the decline in $p_{m}$-dominates, or exactly offsets, the direct substitution effect. Hence, $L_{N} / P_{N}$ increases or stays the same. With additional lags, the relative participation of immigrants in the goods market goes down, and then the labor demand effect-still caused by a decline in $p_{m}$-is dominated by the direct substitution effect, leading to a lower $L_{N} / P_{N}$.

The importance of direct substitution in the interpretation implies that the results are consistent with imperfect capital mobility (i.e., $1-\alpha-\beta>0$ ). This is so because, as discussed in Section 3, when capital mobility is perfect, the direct substitution effect is eliminated, and the only effect on employment comes from the change in $p_{m}$ in the opposite direction - the effect working via labor demand. Hence, if capital mobility were perfect, the two impulse responses should have been mirror images of each other around the zero line.

In terms of the main question in the related literature, the results indicate that significant negative effects of immigration on native-born employment occur only from the fourth lag onwards - i.e., with a delay of a year after immigration. The stock of immigrants, $P_{I} / P_{N}$, when added to the regressions, has highly insignificant coefficients in the two equations. The other results remain unchanged. The lack of significance of the stock of immigrants suggests that the negative effects of immigration are temporary. ${ }^{12}$

\footnotetext{
${ }^{12}$ In order to check the robustness of the results, we modified the basic specifications. First, system was estimated without d_pol and tourists. Second, the model was estimated with total immigration flows. Over
} 
Beyond the interpretation of the results using Table 1, one may carry out an exercise to illustrate the macroeconomic effect working through the relative price. The degree to which the relative price changes in the second panel of Figure 3 mitigate or delay the decline in $L_{N} / P_{N}$, shown in the first panel of Figure 3, can be calculated using equation (9), where $L_{N} / P_{N}$ is a function of $p_{m}$, and assuming reasonable parameter values for the coefficient of $p_{m}$ in this equation. If $\lambda=1, \alpha=0.6, \beta=0.3$, this coefficient equals -0.375 , implying that for each percentage point appreciation, $L_{N} / P_{N}$ increases 0.375 percent. Using this coefficient, one may construct an hypothetical impulse response for native employment that holds $p_{m}$ constant, and corresponds, in the notation of equation $(18)$, to $c_{q}-(-0.375) c_{q}^{\prime}$, $q=1, . ., 9$ - where $c_{q}$ and $c_{q}^{\prime}$ are the "basic" impulse responses, taken from Specification 2 in Table 2 and plotted in Figure 3. ${ }^{13}$ This line ("constant relative price") is plotted in Figure 4, along with the "basic" impulse response. The vertical distance between the "basic" line and the "constant relative price" line depends on the parameter values assumed. Qualitatively, however, Figure 4 indicates that without the macroeconomic effect via the relative price, native employment would have reacted more negatively to immigration (except for the first lag).

the sample period 1990:1-1999:4, immigrants from the former Soviet Union at working age represent about 80 percent of total immigrants in this age range. The exogeneity of the additional flows is much more questionable than those from the former Soviet Union. The results and impulse responses with these two changes remain similar to those reported in Table 2. Additionally, unilateral transfers from abroad, which increase the supply of foreign exchange, and government spending, which affects the demand for goods, can potentially have an impact on the real exchange rate and, thus, on native employment. To test this possibility, unilateral transfers from abroad, in US dollars, and the government spending/GDP ratio were added to the regressions, but they turned out to be insignificant, without altering the other results.

${ }^{13}$ The expression $c_{q}-(-0.375) c_{q}^{\prime}$ can be written as:

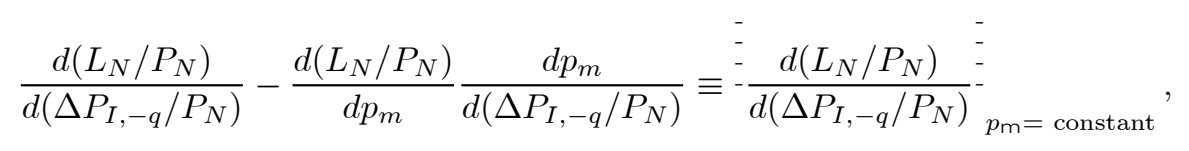

where $\frac{d\left(L_{\mathrm{N}} / P_{\mathrm{N}}\right)}{d\left(\Delta P_{1},-\mathrm{q} / P_{\mathrm{N}}\right)}=c_{q}, \frac{d\left(L_{\mathrm{N}} / P_{\mathrm{N}}\right)}{d p_{\mathrm{m}}}=-0.375$, and $\frac{d p_{\mathrm{m}}}{d\left(\Delta P_{1,-q} / P_{\mathrm{N}}\right)}=c_{q}^{\prime}$. 


\section{Figure 4}

Figure 5 summarizes the effects of immigration on the native-born employment rate during the sample. The "no immigrątion" line is the actual employment rate less the immi-

gration effects, i.e., the exponent of $\ln \frac{L_{N, t}}{P_{N, t}}-{ }^{\mathrm{P}} \underset{q=1}{Q} c_{q} \frac{\Delta P_{I, t-q}}{P_{N, t}}$, where the $c_{q}$ s are the coefficients in the "basic" impulse response. The vertical difference between the "no immigration" and the "actual" lines represents the estimated marginal contribution of the immigration influx. The largest negative effect of immigration occurs in the third quarter of 1992, when the actual native-born employment rate is 2.6 percentage points below its predicted rate. The average such difference over the sample is 1 percentage point. Given that these are percentages out of the working age population, and not out of the labor force, they are quite sizeable. $^{14}$

Figure 5 includes also the "constant relative price" line, using the computation above to control for relative price changes. This line can be interpreted as the hypothetical employment rate for ą constant $p_{m}$, under the parameter assumptions made, and it is defined as the exponent of $\ln \frac{L_{N, t}}{P_{N, t}}-(-0.375){ }_{q=1}^{\mathrm{P}} c_{q}^{\prime} \frac{\Delta P_{I, t-q}}{P_{N, t}}$. As in the discussion of Figure 4, the vertical distance between the "actual" and "constant relative price" lines depends on the parameter values assumed. Qualitatively, however, the employment rate with a constant relative price declines more and sooner than the actual rate, illustrating the moderating effect of the appreciation on native-born employment implied by the model.

\section{Figure 5}

\footnotetext{
${ }^{14}$ If all the reduction in native-born employment accrued to unemployment, the partial contribution of immigration to the total unemployment rate (out of the labor force) would be 3.9 percentage points in 1992:3 and 1.4 percentage points on average. For comparison, the unemployment rate was 12 percent in 1992:3 and 8.5 percent on average.
} 


\subsection{Additional Evidence}

A key element in the present analysis is the participation of immigrants in the labor and the goods markets, as captured by the participation factors $\left(\theta_{y}\right)_{-q}$ and $\left(\theta_{l}\right)_{-q}$. In particular, the empirical results were interpreted to imply that $\left(\theta_{y}\right)_{-q}$ is high relative to $\left(\theta_{l}\right)_{-q}$ for low values of $q$, declining thereafter. Direct evidence is available only on labor participation: $\left(\theta_{l}\right)_{-q}$ can be measured by the ratio of employed immigrants to immigrants in the labor force as a function of quarters since arrival. These ratios are plotted in Figure $6 .{ }^{15}$

\section{Figure 6}

As the figure shows, labor participation increases monotonically with time from arrival. ${ }^{16}$ This behavior is consistent with the interpretation of the impulse responses in Figure 3 as a downward movement along the regions of Table 1 -i.e., that the relative participation in the labor market increases with time since arrival.

An additional aspect of the model that it is interesting to confront with the data is the behavior of the real wage. Equation (4) implies that $w$ should have a (perfect) positive correlation with the native employment rate (in log terms). Note that this positive comovement reflects both mechanisms addressed in this paper: (1) differential participation (stronger in

\footnotetext{
${ }^{15}$ We thank Sarit Cohen for kindly providing these data, produced from the Labor Force Survey. The data refer to immigrants who arrived between late 1989 and early 1992, aged 23-58 at arrival. Note that labor participation in the present context requires employment-i.e., contribution to the supply of goods - rather than participation, as usually defined. Hence, the ratio employment/working-age population would be a more precise indicator for $\left(\theta_{l}\right)_{-q}$. However, these ratios are not available as a function of time since arrival.

${ }^{16}$ Evidence on participation in the goods market is problematic because available data are aggregate. Focusing on residential investment is less problematic, given that new immigrants' share in the housing investment should be much larger than the corresponding share in consumption. We regressed total housing investment on immigration flows and the same control variables and sample as in the other regressions. The estimated (PDL) coefficients - interpreted as the pattern of immigrant housing investment by length of stay and thus as a partial measure of $\left(\theta_{y}\right)_{-q}$ - have a general declining pattern, as expected, with significant coefficients from the 2 nd through the 6 th lag.
} 
the goods market) increases labor demand, leading to both higher real wages and native employment; and (2) direct labor substitution, triggered by increasing total labor supply, generates both lower $w$ and $L_{N} / P_{N}$. These two variables, plotted in Figure 7, display, as predicted, a positive correlation (0.6). ${ }^{17}$

\section{Figure 7}

\section{Conclusions}

The paper examines the effects of mass immigration to Israel during the 1990s on the employment rates of the native-born. Studying the immigration influx to Israel from the former Soviet Union has two important advantages from both the analytical and econometric points of view. The first is the exogenous nature of this immigration influx, which allows the use of reasonably exogenous explanatory variables. The second is that looking at a national economy diminishes to a large extent the bias generated by internal native migration to other areas, which may arise when studying immigration to a particular area of a national economy.

The analysis is carried out within a general equilibrium model that focuses on the macroeconomic effects of immigration on native employment. The model takes into account dynamic effects on both labor supply and labor demand induced by immigration through gradual and differential entry into the labor and the goods markets. These features cannot be dealt with in a partial labor-market equilibrium setup, or using immigration stock data. In particular, the present analysis uncovers an early effect of immigration working through the demand for goods and an increase in the relative price of domestic goods (a real appreciation). The negative employment effect appears only later, with a delay of about a year following arrival.

\footnotetext{
${ }^{17}$ The variables are logged and detrended. The available real wage data include immigrants, who entered low-wage occupations first [see Eckstein and Weiss (1998)]. Hence, the aggregate wage series - used in Figure 7 -is biased downwards, mainly at the beginning of the sample, relative to the relevant wage for native-born.
} 


\section{R eferences}

[1] Altonji, Joseph G. and David Card, 1991. "The Effects of Immigration on the Labor Market Outcomes of Less-Skilled Natives," in J.M. Abowd and R.B.Freeman (eds.). I mmigration, Trade and the Labor Market, University of Chicago Press, (Chicago), 201-234.

[2] Borjas, George J., 1994. "The Economics of Immigration," J ournal of Economic Literature XXXII, 1667-1717.

[3] Borjas, George J., Richard B. Freeman and Lawrence F. Katz, 1997. "How Much Do Immigration and Trade Affect Labor Market Outcomes?" B rookings P apers on E conomic Activity 1, 1-90.

[4] Bruno, Michael and Jeffrey D. Sachs, 1985. Economics of Worldwide Stagflation. Basil Blackwell, (Oxford).

[5] Card, David, 1990. "The Impact of the Mariel Boatlift on the Miami Labor Market," Industrial and Labor R elations R eview, 43(2), 245-257.

[6] Eckstein, Zvi and Ron Shachar, 1996. "On the Transition to Work of New Immigrants: Israel 1990-1992," mimeo.

[7] Eckstein, Zvi and Yoram Weiss, 1998. "The Absorption of Highly Skilled Immigrants: Israel, 1990-1995", mimeo.

[8] Friedberg, Rachel M., 1997. "The Impact of Mass Migration on the Israeli Labor Market," PSTC Working Paper \#97-11, Brown University.

[9] Friedberg, Rachel M. and Jennifer Hunt, 1995. "The Impact of Immigrants on Host Country Wages, Employment and Growth," J ournal of Economic Perspectives 9, $2,23-44$. 
[10] Zimmermann, Klaus F., 1995. "Tackling the European Migration Problem," J ournal of Economic Perspectives 9(2), 45-62. 
Table 2

\begin{tabular}{|c|c|c|c|c|c|c|}
\hline & \multicolumn{2}{|c|}{ (1) PDL } & \multicolumn{2}{|c|}{ (2) PDL } & \multicolumn{2}{|c|}{ (3) Unrestricted } \\
\hline & $\ln \frac{L_{N, t}}{P_{N}}$ & $\ln p_{m, t}$ & $\ln \frac{L_{N, t}}{P_{N}}$ & $\ln p_{m, t}$ & $\ln \frac{L_{N, t}}{P_{N, t}}$ & $\ln p_{m, t}$ \\
\hline Constant & $\begin{array}{c}-0.73^{*} \\
(0.01)\end{array}$ & $\begin{array}{c}0.11^{*} \\
(0.04)\end{array}$ & $\begin{array}{c}-0.74^{*} \\
(0.01)\end{array}$ & $\begin{array}{l}0.12^{*} \\
(0.03)\end{array}$ & $\begin{array}{c}-0.74^{*} \\
(0.01)\end{array}$ & $\begin{array}{c}0.13^{*} \\
(0.03)\end{array}$ \\
\hline time & $\begin{array}{c}0.007^{*} \\
(0.001)\end{array}$ & $\begin{array}{l}-0.007^{*} \\
(0.002)\end{array}$ & $\begin{array}{c}0.008^{*} \\
(0.001)\end{array}$ & $\begin{array}{c}-0.006^{*} \\
(0.002)\end{array}$ & $\begin{array}{c}0.008^{*} \\
(0.001)\end{array}$ & $\begin{array}{l}-0.006^{*} \\
(0.002)\end{array}$ \\
\hline time $^{2} \times 10^{2}$ & $\begin{array}{l}-0.011^{*} \\
(0.001)\end{array}$ & $\begin{array}{l}-0.001 \\
(0.003)\end{array}$ & $\begin{array}{l}-0.012^{*} \\
(0.001)\end{array}$ & $\begin{array}{c}-0.002 \\
(0.003)\end{array}$ & $\begin{array}{c}-0.012^{*} \\
(0.001)\end{array}$ & $\begin{array}{l}-0.001 \\
(0.003)\end{array}$ \\
\hline price of oil & & $\begin{array}{l}0.003^{*} \\
(0.001)\end{array}$ & & $\begin{array}{l}0.003^{*} \\
(0.001)\end{array}$ & & $\begin{array}{l}0.003^{*} \\
(0.001)\end{array}$ \\
\hline tourists & $\begin{array}{l}5.93^{*} \\
(2.80)\end{array}$ & $\begin{array}{c}7.81 \\
(8.75)\end{array}$ & $\begin{array}{c}9.13^{*} \\
(2.19)\end{array}$ & & $\begin{array}{l}9.63^{*} \\
(2.23)\end{array}$ & \\
\hline d_pol & $\begin{array}{c}0.007 \\
(0.004)\end{array}$ & $\begin{array}{c}0.029^{*} \\
(0.011)\end{array}$ & & $\begin{array}{c}0.034^{*} \\
(0.008)\end{array}$ & & $\begin{array}{c}0.036^{*} \\
(0.008)\end{array}$ \\
\hline$\frac{\Delta P_{I, t-1}}{P_{N, t}}$ & $\begin{array}{c}-0.12 \\
(0.66)\end{array}$ & $\begin{array}{c}2.47 \\
(2.07)\end{array}$ & $\begin{array}{c}0.33 \\
(0.59)\end{array}$ & $\begin{array}{c}1.12 \\
(1.51)\end{array}$ & $\begin{array}{c}2.39 \\
(2.39)\end{array}$ & $\begin{array}{c}4.47 \\
(5.91)\end{array}$ \\
\hline$\frac{\Delta P_{I, t-2}}{P_{N, t}}$ & $\begin{array}{c}0.11 \\
(0.22)\end{array}$ & $\begin{array}{c}0.00 \\
(0.65)\end{array}$ & $\begin{array}{c}0.26 \\
(0.21)\end{array}$ & $\begin{array}{l}-0.41 \\
(0.51)\end{array}$ & $\begin{array}{c}0.66 \\
(2.22)\end{array}$ & $\begin{array}{c}2.40 \\
(5.76)\end{array}$ \\
\hline$\frac{\Delta P_{I, t-3}}{P_{N, t}}$ & $\begin{array}{c}0.07 \\
(0.25)\end{array}$ & $\begin{array}{l}-1.26 \\
(0.73)\end{array}$ & $\begin{array}{c}0.03 \\
(0.25)\end{array}$ & $\begin{array}{l}-1.17 \\
(0.74)\end{array}$ & $\begin{array}{l}-1.86 \\
(2.25)\end{array}$ & $\begin{array}{r}-11.90 \\
(6.17)\end{array}$ \\
\hline$\frac{\Delta P_{I, t-4}}{P_{N, t}}$ & $\begin{array}{l}-0.15 \\
(0.21)\end{array}$ & $\begin{array}{c}-1.64^{*} \\
(0.65)\end{array}$ & $\begin{array}{l}-0.28 \\
(0.21)\end{array}$ & $\begin{array}{l}-1.38^{*} \\
(0.61)\end{array}$ & $\begin{array}{c}0.09 \\
(2.25)\end{array}$ & $\begin{array}{c}2.20 \\
(6.09)\end{array}$ \\
\hline$\frac{\Delta P_{I, t-5}}{P_{N, t}}$ & $\begin{array}{l}-0.49^{*} \\
(0.13)\end{array}$ & $\begin{array}{c}-1.43^{*} \\
(0.39)\end{array}$ & $\begin{array}{c}-0.62^{*} \\
(0.15)\end{array}$ & $\begin{array}{l}-1.23^{*} \\
(0.36)\end{array}$ & $\begin{array}{c}0.01 \\
(2.26)\end{array}$ & $\begin{array}{c}-12.50^{*} \\
(6.21)\end{array}$ \\
\hline$\frac{\Delta P_{I, t-6}}{P_{N, t}}$ & $\begin{array}{c}-0.86^{*} \\
(0.20)\end{array}$ & $\begin{array}{l}-0.96 \\
(0.57)\end{array}$ & $\begin{array}{c}-0.92^{*} \\
(0.24)\end{array}$ & $\begin{array}{l}-0.95 \\
(0.59)\end{array}$ & $\begin{array}{l}-5.78^{*} \\
(2.22)\end{array}$ & $\begin{array}{c}2.70 \\
(6.34)\end{array}$ \\
\hline$\frac{\Delta P_{I, t-7}}{P_{N, t}}$ & $\begin{array}{l}-1.17^{*} \\
(0.26)\end{array}$ & $\begin{array}{l}-0.55 \\
(0.79)\end{array}$ & $\begin{array}{l}-1.12^{*} \\
(0.33)\end{array}$ & $\begin{array}{l}-0.73 \\
(0.73)\end{array}$ & $\begin{array}{l}-3.50 \\
(2.25)\end{array}$ & $\begin{array}{l}-0.02 \\
(6.38)\end{array}$ \\
\hline$\frac{\Delta P_{I, t-8}}{P_{N, t}}$ & $\begin{array}{l}-1.35^{*} \\
(0.22)\end{array}$ & $\begin{array}{c}-0.52 \\
(0.64)\end{array}$ & $\begin{array}{l}-1.16^{*} \\
(0.35)\end{array}$ & $\begin{array}{l}-0.80 \\
(0.44)\end{array}$ & $\begin{array}{l}-3.82 \\
(2.08)\end{array}$ & $\begin{array}{l}-7.82 \\
(5.95)\end{array}$ \\
\hline$\frac{\Delta P_{I, t-9}}{P_{N, t}}$ & $\begin{array}{l}-1.33^{*} \\
(0.45)\end{array}$ & $\begin{array}{l}-1.17 \\
(1.31)\end{array}$ & $\begin{array}{l}-0.97 \\
(0.62)\end{array}$ & $\begin{array}{l}-1.36 \\
(1.32)\end{array}$ & $\begin{array}{l}-3.46 \\
(1.91)\end{array}$ & $\begin{array}{l}-4.26 \\
(5.41)\end{array}$ \\
\hline$\overline{\mathrm{R}^{2}}$ & 0.94 & 0.95 & $\overline{0.93}$ & 0.95 & 0.94 & 0.96 \\
\hline D.W. & 1.62 & 2.34 & 1.70 & 2.26 & 1.72 & 2.07 \\
\hline
\end{tabular}




\section{N otes:}

1. tourists: number of tourists.

d_pol: political dummy variable taking the value 1 when the prime minister in office is from the Labor Party, and 0 when the prime minister is from the Likud Party.

2. Standard errors are in parentheses. Coefficients significant at the $5 \%$ level are denoted by an asterisk.

3. The regression sets are estimated using SUR. The regressions entitled "PDL" are estimated using a 3rd order PDL.

4. Sample period: 1990:I - 1999:IV. The lags of the immigration flows do not shorten the sample as they go back to the relevant periods prior to the sample. 


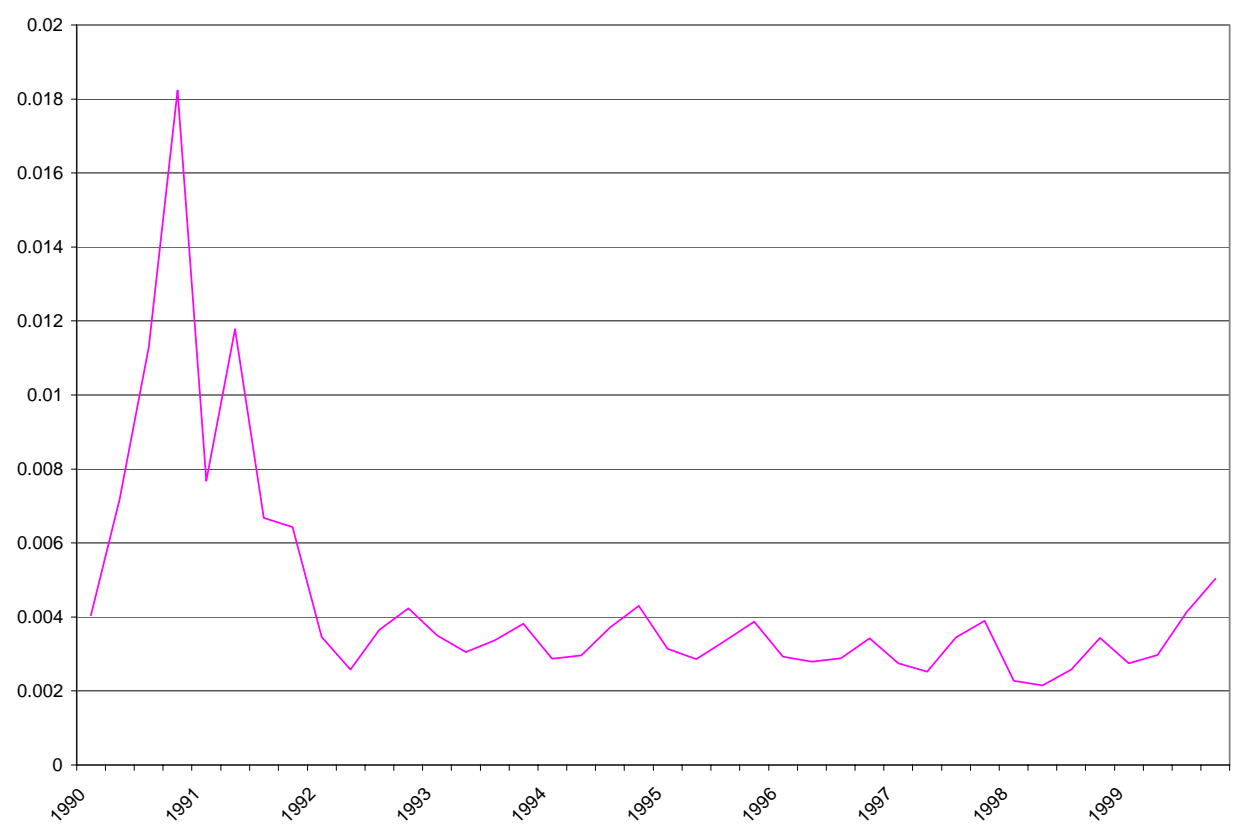

Figure 1: Immigration Flows (Fraction of Native Working-Age Population)

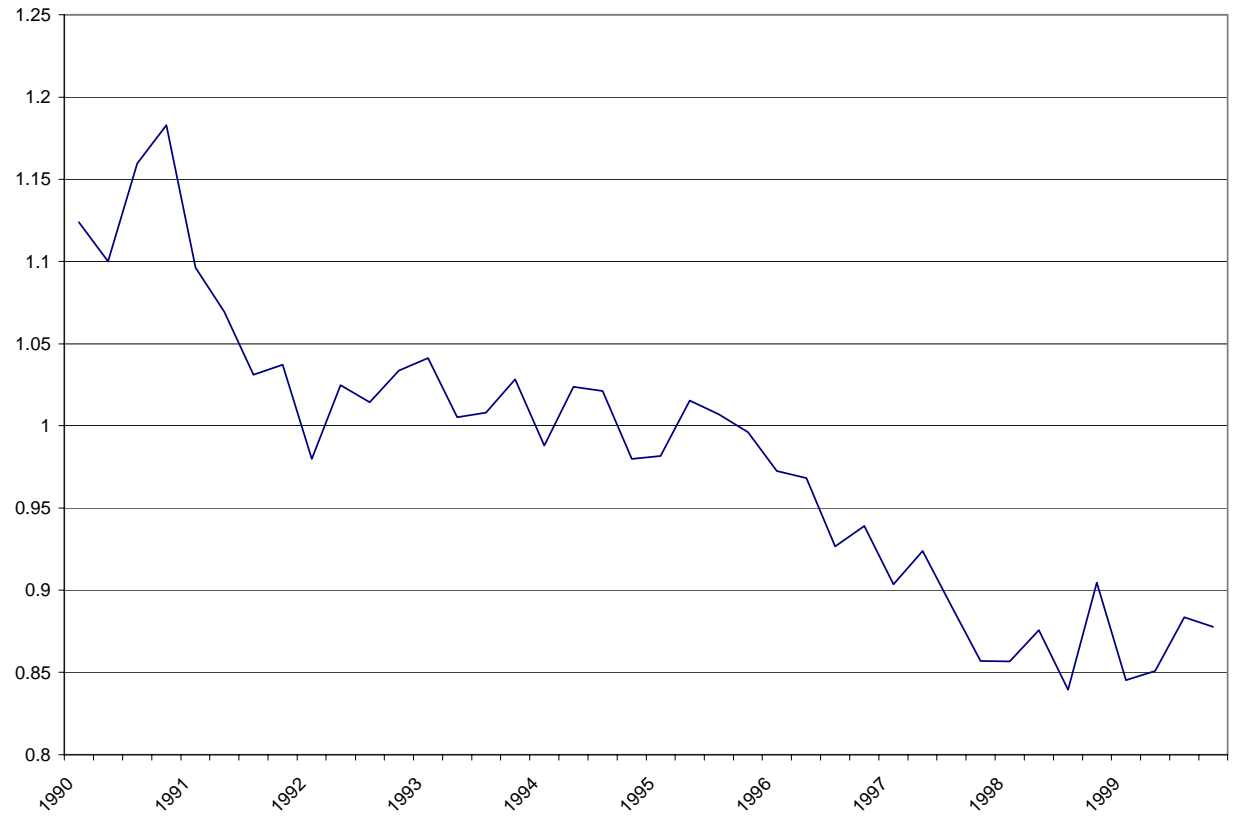

Figure 2: Relative Price of Imports 
Figure 3: Coefficients of Immigration Flows - Table 2 - Specification 2 (with $95 \%$ confidence bands)

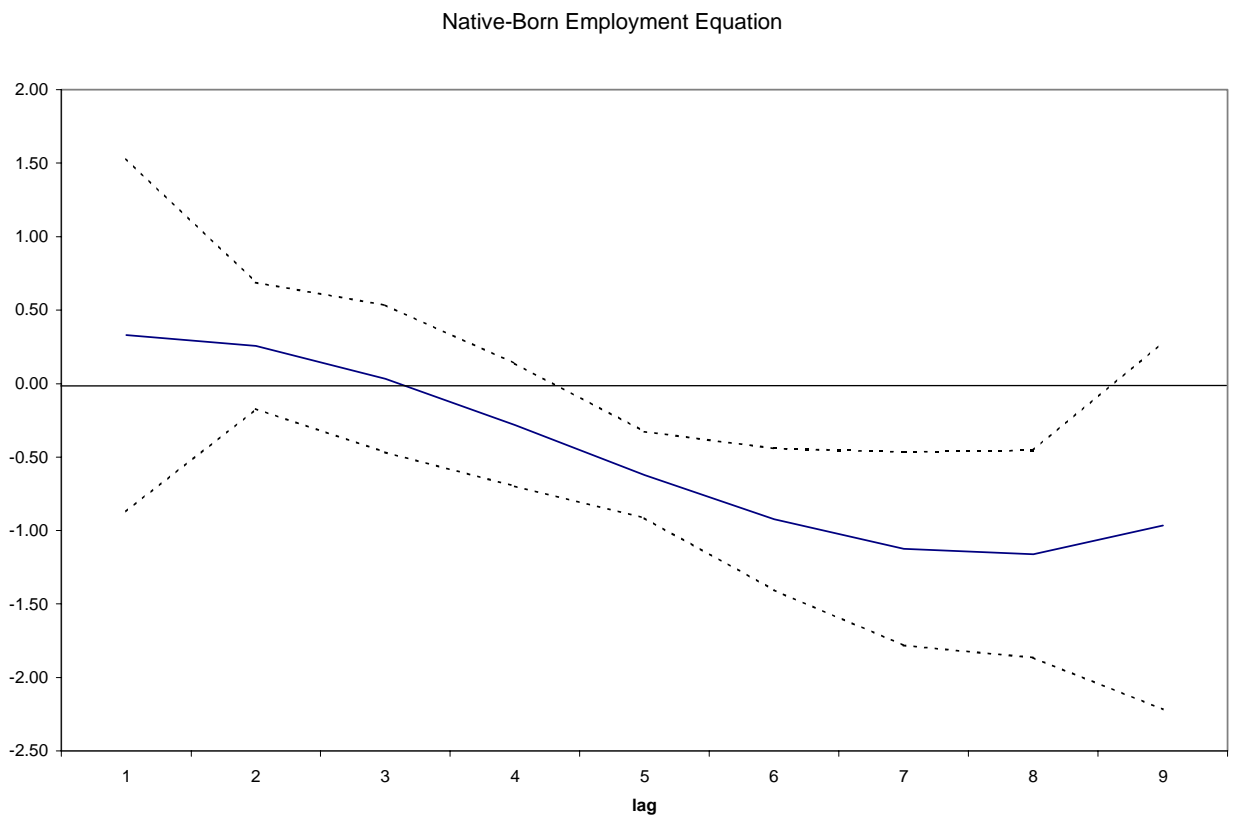

Relative Price Equation

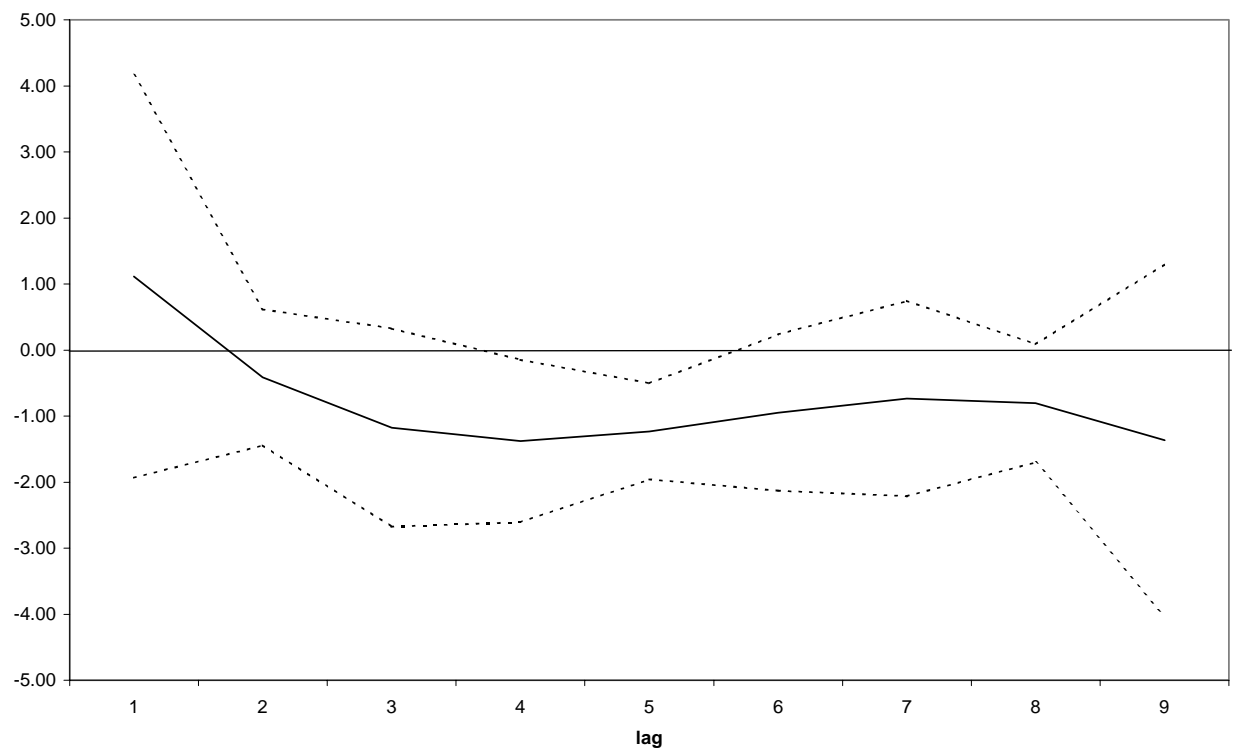




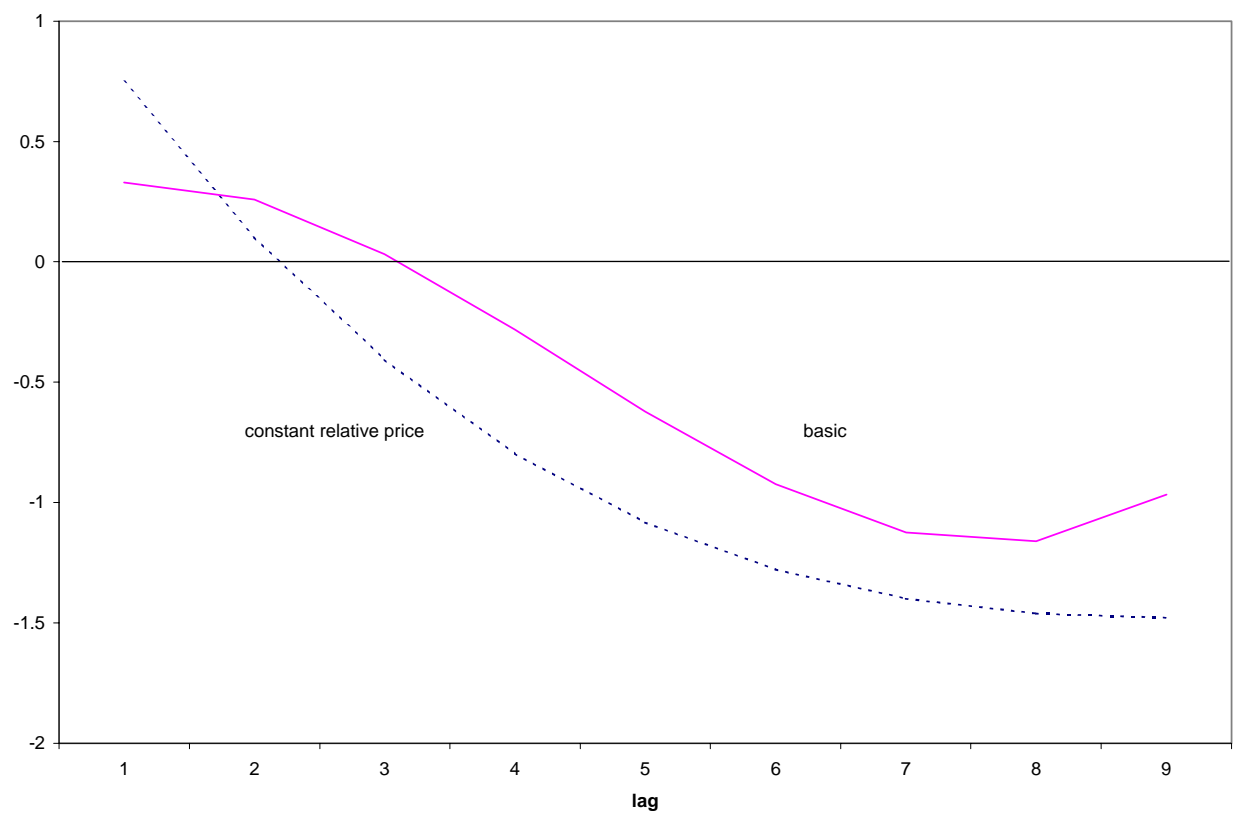

Figure 4: Coefficients of Immigration Flows in the Employment Equation

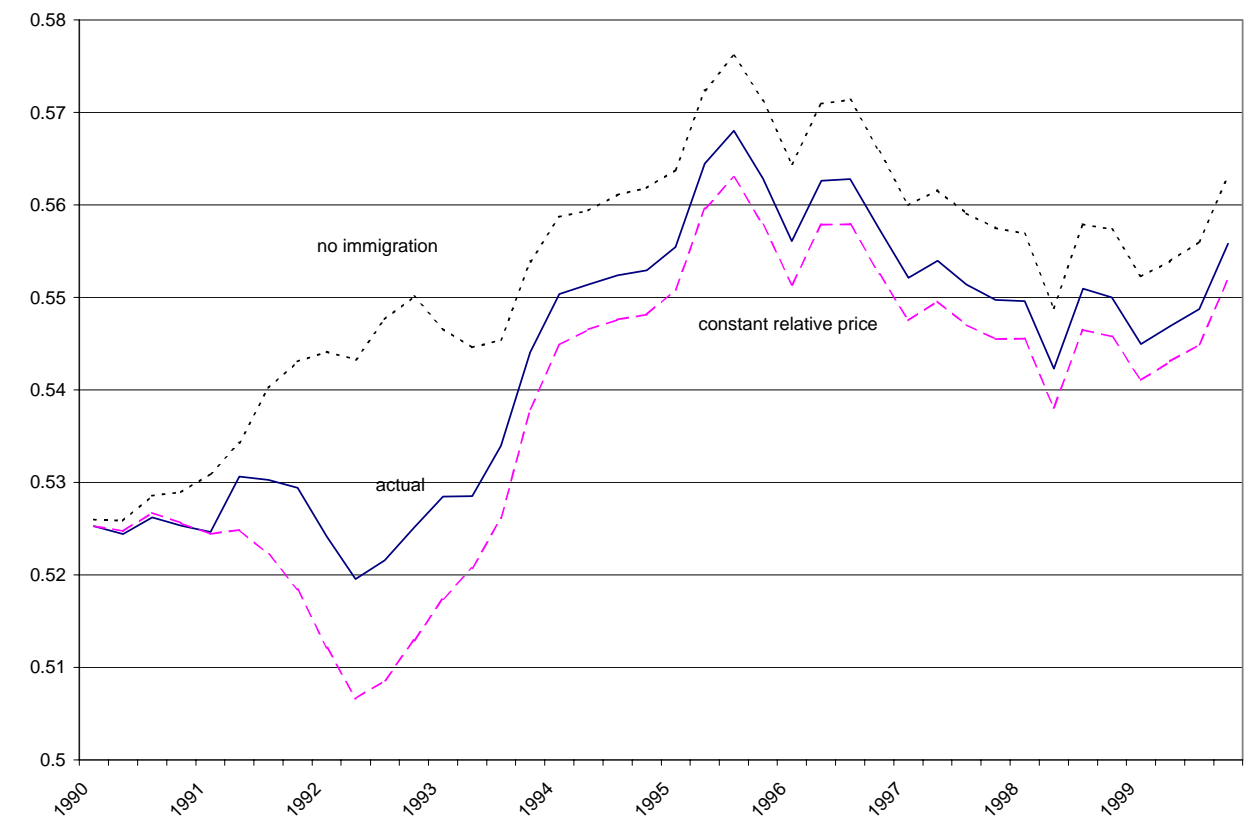

Figure 5: Native-Born Employment (Fraction of Working-Age Population) 


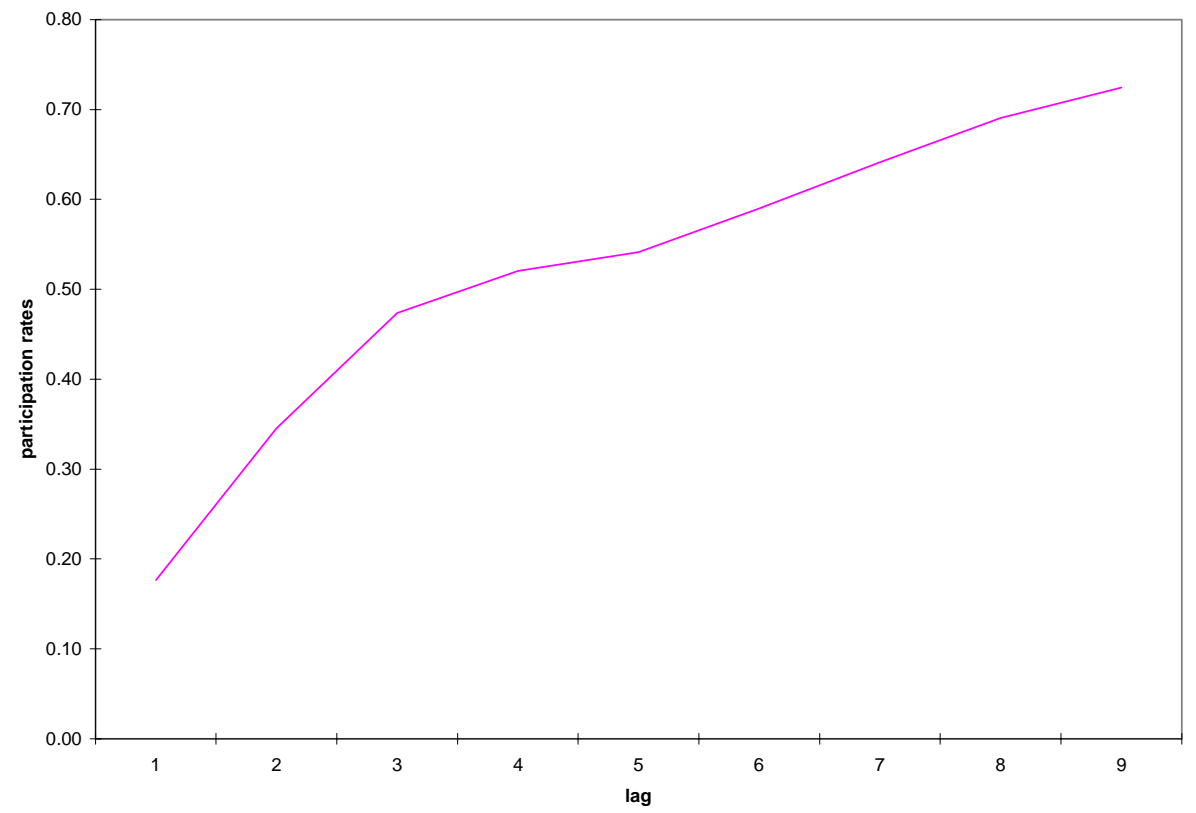

Figure 6: Labor Participation Factors

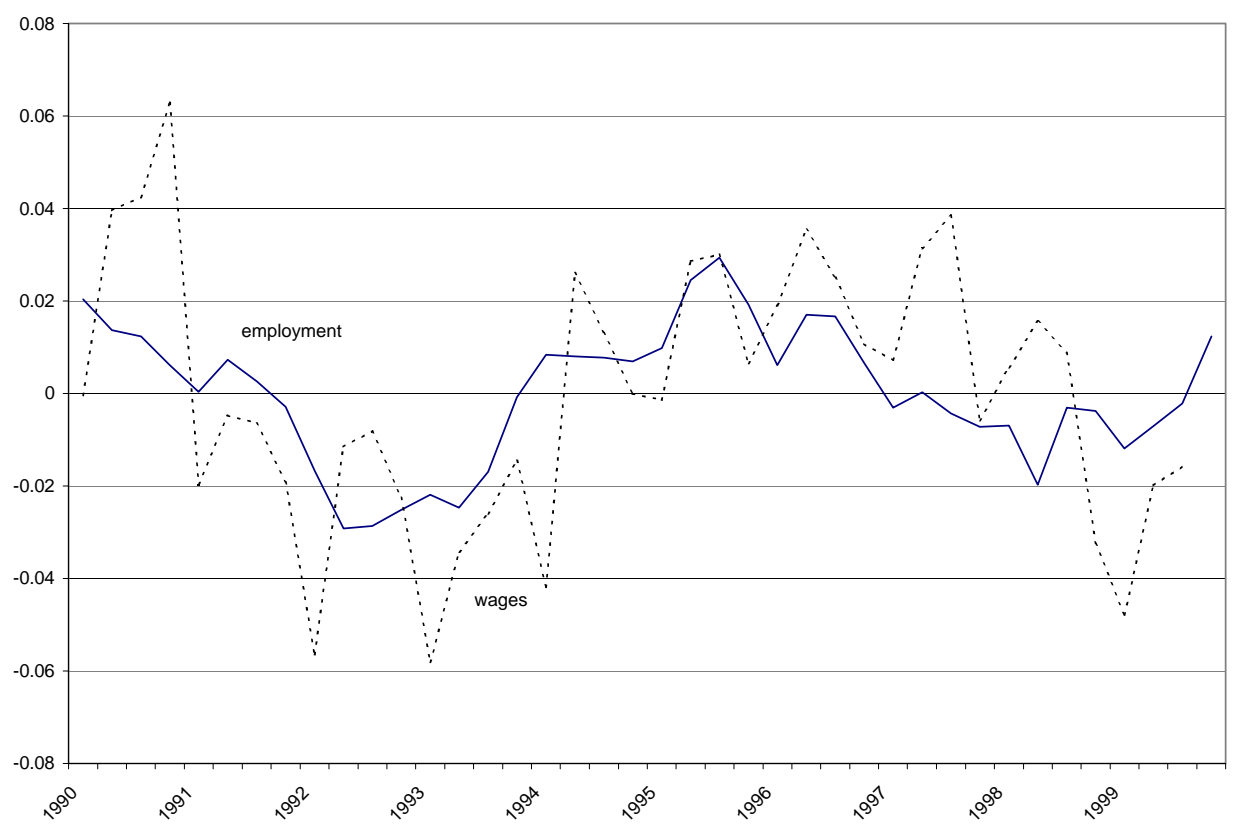

Figure 7: Detrended Log Native Employment Rate and Real Wages 


\section{IZA Discussion Papers}

No.

Author(s)

B. R. Chiswick

Y. Liang Lee

P. W. Miller

461

M. Gurgand

D. N. Margolis

462

B. R. Chiswick

Y. Liang Lee

P. W. Miller

463

464

J. Ermisch

M. Francesconi

J. E. Askildsen

E. Bratberg

$\varnothing$. A. Nilsen
A. Venturini
C. Villosio

J. Wagner

\section{R. Lalive}

J. C. van Ours

J. Zweimüller
A. Cigno
F. C. Rosati
L. Guarcello

B. R. Chiswick

Y. Liang Lee

P. W. Miller

472 R. Foellmi

J. Zweimüller

473

474

475
L. Bellmann

A. Kölling

Z. Hercowitz

E. Yashiv
Title

Area

Date

Family Matter: The Role of the Family in

Immigrants' Destination Language Acquisition

Welfare and Labor Earnings:

3

An Evaluation of the Financial Gains to Work

The Determinants of the Geographic

Concentration among Immigrants: Application to

Australia

Labor Supply Dynamics, Unemployment and

Human Capital Investments

The Hold-Down Problem and the Boundaries of the Firm: Lessons from a Hidden Action Model with Endogenous Outside Option

Intergenerational Social Mobility and Assortative Mating in Britain

Unemployment, Labour Force Composition and 1 Sickness Absence: A Panel Data Study

Are Immigrants Competing with Natives in the Italian Labour Market? The Employment Effect

The Impact of Risk Aversion, Role Models, and the Regional Milieu on the Transition from Unemployment to Self-Employment: Empirical Evidence for Germany

The Effect of Benefit Sanctions on the Duration of Unemployment

Does Globalisation Increase Child Labour?

Immigrants' Language Skills and Visa Category

Structural Change and the Kaldor Facts of Economic Growth

A pint a day raises a man's pay, but smoking blows that gain away

Unions, Works Councils and Plant Closings in

3

04/02

$03 / 02$

03/02

$3 / 02$

$3 / 02$

$4 / 02$
A Macroeconomic Experiment in Mass

Immigration 